\title{
Effect of Different Dress Weight Categories on Yield Part Percentage and Relationship of Live and Dress Weight of Broiler Carcasses Slaughter at Different Conditions
}

\author{
R. A. U. J. MARAPANA* \\ Department of Food Science and Technology, Faculty of Applied Sciences, University of Sri Jayewardenepura, \\ Gangodawila, Nugegoda, Sri Lanka
}

\begin{abstract}
Commercially reared mixed sex broilers were utilized to determine the effect of dress carcass weight on percentage yield of broiler parts, breast meat yield in weight category of <1.0, 1.0-1.2, 1.2-1.4, 1.4-1.6, 1.6-1.8, 1.8-2.0 and $>2.0 \mathrm{~kg}$. Then $\mathrm{pH}$, cooking yield and moisture content of the breast meat with different time intervals ( 0 hr, 12 hrs, 24 hrs, 36 hrs, 48 hrs) and proximate compositions of meat were measured. Percentage yield of whole leg, thigh, breast, back and rib, neck, wings, gizzards, heart, liver, drumstick and total giblet were significantly affected by dress carcass weight at $p<0.05$. Yield of body components changed with the increasing body weight. $p H$ values was significantly affected by time after slaughtering and finally it's reduced up to 5.69 at 48 hrs after slaughtering. Suitable processing weight of broiler carcass to gain maximum breast yield is $>2.0 \mathrm{~kg}$ which could be obtained highest fillet yield. To gain highest cooking yield (83.55\%), carcass should be cooked immediately after slaughtering. Regression analyses revealed that linear relationship between live weight and dress weight of broiler carcass at different transport distance, starvation period, life time, and cage system at $p<0.01$ except $>150 \mathrm{~kg}$ transport distance. Based on the dressing percentage, weight of total edible meat, it may be concluded that broiler chickens are optimally slaughtered up to $2.0 \mathrm{~kg}$ live weight. Live and dress weight had highly significant relationship with the transport distance, starvation period, life time, cage system and live weight category.
\end{abstract}

Keywords: Broiler carcasses, Live weight, Dress weight, Cage system, Transport distance

\section{Introduction}

The consumption of chicken meat is one of increasing significance in Sri Lanka and per head consumption is still rising (Department of Animal Production and Health, 2012). Generally, chicken meat production is one of the sectors that adapted the quickest to the change, which occurred in the consumer preferences. Hence Chicken meat is sold as a whole as well as cut-up into parts that give different cooking and taste choices (Heath, 1979; Yavuz, et al., 2004). So, demand for high quality cut-up parts have driven the poultry industry to change its marketing practices. Today, with the vast majority of poultry being marketed in this manner, yield of high value items such as breasts and broiler filets have become critical to processors (Young et al., 2001). The carcass yield of a broiler is a primary concern to the producer, processor and the consumer but there is a wide divergence of opinion as how to calculate the carcass yield. The need for uniformity in the calculation is emphasized by the fact that the reported eviscerated yields of broiler carcass expressed as percentage of live weight ranges from $60-$ $80 \%$ (Guenter et al., 1995). The dressing percentage and relative meat yield in the different parts could be altered by several factors such as strain, sex, length of feed withdrawal before processing, length of starvation prior to killing, the birds transport distance from farm to slaughter plant, the life span of birds and the birds rearing system (Mcnally and Spicknall, 1949; Moran and Larmond, 1970; Bouwkamp, et al., 1973). So, poultry processors generally select broilers that will reach market weight at a reasonable age in order to maximize profit. Oluyemi and Roberts (2000) observed that at day old ( $42 \mathrm{~g}$ live weight), the broiler dressed carcass weight expressed as live weight was $30 \%$ while at $3000 \mathrm{~g}$ live weight, the dressed carcass percentage rose to $57 \%$. In a similar pattern, the meat yield of any animal increased with increasing slaughter weight. The percentage of each part of the body determine physiological age and stage of maturity of the birds (Rickefs, 1985). Some parts such as thigh, drumstick and breast have greater commercial value. So, the percentage yield of body parts is important to define

*Corresponding author, E-mail: umarapana@sci.sjp.ac.lk 
the age and slaughter weight and to predict the weight of parts. Therefore it is important for the poultry product manufactures to anticipate yield patterns over a wide range of rearing conditions.

The proportions of basic carcass parts (breasts, drumsticks and thighs), the chemical composition of the carcass parts are regarded as vital parameters determining overall broiler meat quality (Lewis et al., 1997; Suto et al., 1998).

For these reasons, the present study was undertaken to determine the percentage yield of parts at different slaughter weight and also to investigate different slaughter weight on broiler breast yield and proximate composition of different parts at each slaughter weight. Further, $\mathrm{pH}$, cooking yield and moisture content of breast meat at each weight category and different time interval after slaughtering were investigated. A major emphasis to develop regression formula between live weight and dress weight of broiler chicken that could be used to predict dress weight as affected by with and without giblets, starvation interval, transport distance, different life span, rearing system and live weight categories.

\section{Materials and Methods}

Thirty four samples were randomly selected at each slaughtering weight category ranging 1.2-1.4, 1.4-1.6, 1.6$1.8,1.8-2.0,>2.0 \mathrm{Kg}$. After evisceration, the defeathered birds were weighed, dissected all internal and external organs (head, neck, leg, wing). The viscera were removed as for the usual dressing of poultry carcasses. Heart, liver (minus the gall bladder), empty skinned gizzard were trimmed of extraneous tissue and weighed individually and their sum of weights 'giblets' was taken. The dressed weights obtained were expressed as a percentage of the live weights and yield parts expressed as a percentage of dress carcass weight. $\mathrm{pH}$, moisture content and cooking yield of breast meat were measured in every weight category and immediate after slaughtering, 0 hr, 12 hrs, 24 hrs, 36 hrs, 48 hrs and 56 hrs respectively.

180 chickens were randomly selected according to transport distance $(<50,50-100,100-150,>150 \mathrm{~km})$, life time $(<35$, 35-40, 40-45 days), starvation time ( $<14,16-18,24-26$ hrs) rearing system (open and close) and at different live weight category (1200-1400, 1400-1600, 1600-1800, 1800$2000,>2000 \mathrm{~g})$. All birds from each group were processed at the same time. Each birds was weighed at slaughter, killed by exsanguinations, allowed for bleeding, scalded at $63{ }^{\circ} \mathrm{C}$ for approximately 120 s, placed in a rotary drum for 30 s, processed by removing head, neck, shank, eviscerated and the carcasses were individually weighed to obtain the dressed weight.

\section{Proximate composition of different yield parts}

Proximate analyses (total solid, crude fat, crude protein and ash) were carried using the procedures of AOAC (1980) on different yield parts (breast, drumstick, thigh and wings) of broiler chicken.

\section{Percentage of drip loss and cooking yield}

A $2 \mathrm{~cm}$ thick slice was excised just after slaughter at the breast, suspended within a net in a plastic bag and stored at 4 ${ }^{\circ} \mathrm{C}$. The percent change in weight over the subsequent $24 \mathrm{hrs}$ was taken as the drip loss, as described by Honikel (1998).

Cooking yield was determined by the method described by Petracci et al., (2004). Whole breast was individually weighed and cooked in a convection oven on aluminum trays at $180^{\circ} \mathrm{C}$ until the core temperature reached $80^{\circ} \mathrm{C}$. The breast meat were then allowed to equilibrate to room temperature and reweighed, and cooking yield determined as percentage of cooked breast weight by the sample.

\section{Statistical analysis}

All data were expresses as a percentage of live weight. Effect of dressed carcass weight on percentage yield of parts was determined using CRD design with 32 replicates.

The data was then analyzed by regression between live and dress weight using the SPSS 10.0 software. Regression equations for live weight and dress weight data in the starvation period, transport distance, life span, rearing system and live weight categories were fitted to the following regression model: linear function of $\mathrm{DW}=\mathrm{B}_{0}+\beta_{1} \mathrm{LW}$. If the linear was non-significant, then quadratic function was fit.

\section{Results and Discussion}

Weight of body components are shown in Table 1. As expected, a significant $(\mathrm{p}<0.05)$ effect of weight category was present for all components. Oluyemi and Roberts (2000) reported the body parts of the birds fall into three groups in respect of their stages of development. These stages are the early maturing organ, the intermediate and the late maturing parts. The weights of the heart, liver and gizzard were highest in the less than $1.0 \mathrm{~kg}$ weight bracket (Table 1). This indicated that these organs are early maturing ones, in agreement with Oluyemi and Roberts (2000). The weight of total giblets were decreased $(p<0.05)$ as the weight of the animal increased. Most of the other primal cuts (breast, thigh and back) increased linearly $(p<0.05)$ as the slaughter weight of the bird increased. 
Table1. Effect of body weight category on percentage yield of parts

\begin{tabular}{|c|c|c|c|c|c|c|c|}
\hline \multirow{2}{*}{$\begin{array}{l}\text { Means of } \\
\text { parts \% }\end{array}$} & \multicolumn{7}{|c|}{ Weight category (Kg) } \\
\hline & $<1.0$ & $1.0-1.2$ & $1.2-1.4$ & $1.4-1.6$ & $1.6-1.8$ & $1.8-2.0$ & $>2.0$ \\
\hline \multirow[t]{2}{*}{ Whole leg } & $31.21^{\mathrm{a}}$ & $32.49^{b}$ & $32.22^{\mathrm{ab}}$ & $32.20^{\mathrm{ab}}$ & $33.00^{\mathrm{b}}$ & $33.21^{\mathrm{b}}$ & $32.58^{\mathrm{b}}$ \\
\hline & \pm 2.32 & \pm 2.85 & \pm 1.51 & \pm 2.62 & \pm 1.99 & \pm 1.23 & \pm 1.82 \\
\hline \multirow[t]{2}{*}{ Drumstick } & $12.87^{\mathrm{a}}$ & $12.94^{\mathrm{ab}}$ & $12.94^{\mathrm{ab}}$ & $13.14^{\mathrm{ab}}$ & $13.19^{a b}$ & $13.53^{b}$ & $13.49^{b}$ \\
\hline & \pm 1.01 & \pm 1.17 & \pm 0.81 & \pm 0.97 & \pm 1.25 & \pm 1.07 & \pm 1.24 \\
\hline \multirow[t]{2}{*}{ Thigh } & $18.08^{\mathrm{a}}$ & $19.99^{b}$ & $19.53^{b}$ & $19.72^{b}$ & $19.66^{\mathrm{b}}$ & $19.93^{b}$ & $19.30^{\mathrm{b}}$ \\
\hline & \pm 2.03 & \pm 1.48 & \pm 1.13 & \pm 1.71 & \pm 1.56 & \pm 1.71 & \pm 1.84 \\
\hline \multirow[t]{2}{*}{ Breast } & $25.28^{\mathrm{a}}$ & $25.82^{\mathrm{ab}}$ & $26.23^{\mathrm{ab}}$ & $26.17^{\mathrm{ab}}$ & $26.35^{\mathrm{ab}}$ & $27.61^{\mathrm{c}}$ & $26.79^{b c}$ \\
\hline & \pm 2.74 & \pm 1.86 & \pm 1.87 & \pm 1.99 & \pm 1.43 & \pm 2.03 & \pm 1.68 \\
\hline \multirow[t]{2}{*}{ Back \& rib } & $21.33^{\mathrm{ab}}$ & $20.96^{\mathrm{ab}}$ & $20.47^{\mathrm{a}}$ & $20.44^{\mathrm{a}}$ & $20.21^{\mathrm{a}}$ & $20.22^{\mathrm{a}}$ & $21.59^{b}$ \\
\hline & \pm 1.97 & \pm 2.01 & \pm 1.51 & \pm 3.17 & \pm 1.64 & \pm 1.52 & \pm 1.88 \\
\hline \multirow[t]{2}{*}{ Neck } & $3.72^{b}$ & $3.46^{\mathrm{a}}$ & $3.22^{\mathrm{a}}$ & $3.20^{\mathrm{a}}$ & $3.25^{\mathrm{a}}$ & $3.22^{\mathrm{a}}$ & $3.25^{\mathrm{a}}$ \\
\hline & \pm 0.62 & \pm 0.37 & \pm 0.46 & \pm 0.46 & \pm 0.46 & \pm 0.50 & \pm 0.43 \\
\hline \multirow[t]{2}{*}{ Wings } & $11.98^{c}$ & $11.03^{b}$ & $11.06^{b}$ & $10.87^{b}$ & $10.18^{\mathrm{a}}$ & $9.97^{\mathrm{a}}$ & $10.22^{\mathrm{a}}$ \\
\hline & \pm 1.00 & \pm 0.58 & \pm 0.61 & \pm 0.67 & \pm 1.94 & \pm 1.04 & \pm 0.45 \\
\hline \multirow[t]{2}{*}{ Gizzard } & $2.30^{\mathrm{c}}$ & $1.92^{\mathrm{b}}$ & $1.90^{\mathrm{b}}$ & $1.77^{\mathrm{b}}$ & $1.84^{\mathrm{b}}$ & $1.57^{\mathrm{a}}$ & $1.54^{\mathrm{a}}$ \\
\hline & \pm 0.44 & \pm 0.44 & \pm 0.47 & \pm 0.32 & \pm 0.40 & \pm 0.25 & \pm 0.33 \\
\hline \multirow[t]{2}{*}{ Liver } & $3.89^{\mathrm{e}}$ & $3.17^{\mathrm{d}}$ & $2.93^{\mathrm{cd}}$ & $2.84^{\mathrm{bc}}$ & $2.77^{b c}$ & $2.58^{\mathrm{ab}}$ & $2.39^{\mathrm{a}}$ \\
\hline & \pm 0.87 & \pm 0.77 & \pm 0.36 & \pm 0.43 & \pm 0.52 & \pm 0.32 & \pm 0.51 \\
\hline \multirow[t]{2}{*}{ Heart } & $1.11^{\mathrm{d}}$ & $0.76^{\mathrm{c}}$ & $0.73^{b c}$ & $0.62^{a}$ & $0.66^{\mathrm{ab}}$ & $0.69^{a b c}$ & $0.62^{\mathrm{a}}$ \\
\hline & \pm 0.29 & \pm 0.11 & \pm 0.16 & \pm 0.15 & \pm 0.14 & \pm 0.077 & \pm 0.086 \\
\hline \multirow[t]{2}{*}{ Total giblets } & $7.31^{\mathrm{d}}$ & $5.86^{\mathrm{c}}$ & $5.57^{\mathrm{cb}}$ & $5.25^{\mathrm{bc}}$ & $5.29^{\mathrm{ab}}$ & $4.85^{\mathrm{b}}$ & $4.55^{\mathrm{a}}$ \\
\hline & \pm 1.22 & \pm 0.98 & \pm 0.75 & \pm 0.75 & \pm 0.62 & \pm 0.66 & \pm 0.43 \\
\hline \multirow[t]{2}{*}{ Drain loss } & $7.64^{c}$ & $5.79^{\mathrm{abc}}$ & $6.82^{b c}$ & $6.98^{\mathrm{bc}}$ & $6.89^{b c}$ & $5.48^{\mathrm{ab}}$ & $4.87^{\mathrm{a}}$ \\
\hline & \pm 5.90 & \pm 5.19 & \pm 2.22 & \pm 1.88 & \pm 2.22 & \pm 2.05 & \pm 3.11 \\
\hline
\end{tabular}

abcd different letters in the same row are significantly different at $\mathrm{p}<0.05$, (Mean $\pm \mathrm{SD}$ )

Breast meat yield is the carcass component with the highest economic value, if the bird is considered as a whole. During the production cycle, breast meat continuously increases as a percentage of body weight. Similar pattern have been noted by Acar et al., (1993). Therefore, the success of poultry meat production has been strongly related to improvements in growth and carcass yield, mainly by increasing breast proportion. De bone breast muscle weight occupies the greatest share in the total weight as it is apparent from the results of the proportion of part weights (Table 2). Highest breast drip loss was reported in $1.6-1.8 \mathrm{~kg}$ body weight categories. However, lowest breast drip loss noted in more than $2 \mathrm{~kg}$ weight category. 
Table 2. Effect of body weight category on different percentage yield of breast

\begin{tabular}{|c|c|c|c|c|c|c|c|}
\hline \multirow[t]{2}{*}{ Means of parts \% } & \multicolumn{7}{|c|}{ Weight category (Kg) } \\
\hline & $\begin{array}{l}<1.0 \\
\end{array}$ & $1.0-1.2$ & $1.2-1.4$ & $1.4-1.6$ & $1.6-1.8$ & $1.8-2.0$ & $>2.0$ \\
\hline De bone breast & $60.30^{\mathrm{a}}$ & $65.33^{\mathrm{b}}$ & $69.08^{c}$ & $67.01^{\mathrm{bc}}$ & $67.03^{\mathrm{bc}}$ & $65.96^{\mathrm{bc}}$ & $69.08^{d}$ \\
\hline muscle weight & \pm 0.10 & \pm 2.49 & \pm 1.71 & \pm 2.90 & \pm 1.30 & \pm 2.80 & \pm 1.36 \\
\hline \multirow[t]{2}{*}{ Loose meat } & $15.76^{\mathrm{a}}$ & $14.9^{\mathrm{b}}$ & $15.14^{\mathrm{b}}$ & $15.14^{\mathrm{b}}$ & $14.93^{\mathrm{b}}$ & $14.14^{\mathrm{c}}$ & $14.47^{\mathrm{bc}}$ \\
\hline & \pm 1.99 & \pm 1.36 & \pm 1.39 & \pm 1.39 & \pm 1.18 & \pm 1.21 & \pm 1.09 \\
\hline \multirow[t]{2}{*}{ Fillet } & $14.27^{\mathrm{a}}$ & $14.94^{\mathrm{ab}}$ & $15.61^{\mathrm{c}}$ & $15.25^{\mathrm{bc}}$ & $14.60^{\mathrm{ab}}$ & $14.27^{\mathrm{a}}$ & $15.61^{\mathrm{c}}$ \\
\hline & \pm 2.24 & \pm 1.19 & \pm 2.21 & \pm 1.50 & \pm 1.52 & \pm 1.32 & \pm 0.27 \\
\hline \multirow[t]{2}{*}{ Breast bone } & $20.31^{\mathrm{d}}$ & $17.03^{c}$ & $16.59^{\mathrm{bc}}$ & $15.51^{\mathrm{ab}}$ & $14.63^{\text {a }}$ & $15.11^{\text {a }}$ & $15.05^{\mathrm{a}}$ \\
\hline & \pm 3.99 & \pm 2.60 & \pm 0.04 & \pm 2.13 & \pm 1.92 & \pm 1.67 & \pm 1.29 \\
\hline \multirow[t]{2}{*}{ Breast drip loss } & $4.40^{b}$ & $3.93^{\mathrm{ab}}$ & $2.50^{\mathrm{ab}}$ & $3.21^{\mathrm{ab}}$ & $4.41^{\mathrm{b}}$ & $2.76^{\mathrm{ab}}$ & $2.36^{\mathrm{a}}$ \\
\hline & \pm 0.02 & \pm 0.05 & \pm 0.04 & \pm 0.04 & \pm 0.07 & \pm 0.02 & \pm 0.06 \\
\hline \multirow{2}{*}{$\begin{array}{l}\text { Av. Total breast } \\
\text { weight } \% \text { per dress } \\
\text { carcass }\end{array}$} & $25.28^{\mathrm{b}}$ & $25.82^{\mathrm{a}}$ & $26.23^{b}$ & $26.17^{b}$ & $26.36^{\mathrm{b}}$ & $27.62^{\mathrm{a}}$ & $26.80^{\mathrm{a}}$ \\
\hline & \pm 2.74 & \pm 1.86 & \pm 1.87 & \pm 1.99 & \pm 1.43 & \pm 2.03 & \pm 1.68 \\
\hline $\begin{array}{l}\text { Av. Total breast } \\
\text { weight (g) }\end{array}$ & $243.20^{\mathrm{a}}$ & $282.92^{b}$ & $346.00^{\mathrm{bc}}$ & $393.02^{c}$ & $443.30^{\mathrm{cd}}$ & $522.86^{\mathrm{de}}$ & $533.35^{\mathrm{e}}$ \\
\hline
\end{tabular}

abcd different letters in the same row are significantly different at $\mathrm{p}<0.05$, (Mean $\pm \mathrm{SD}$ )

Results concerning the percentage distribution of part weights are compatible with the data in the literature (Moran et al., 1969; Orr et al., 1984). When a comparison is made according to groups, the debone breast muscle weight share in the total weight was increased depending on the carcass weight, and the breast bone share decreased. Proximate component of drumstick, thigh, breast and wings are presented in Table 3. 
Marapana R. : J. Food Sci. Technol. Nepal, Vol. 9 (31-38), 2016

Table 3. Effect of weight category on proximate component of various body parts of broiler carcass

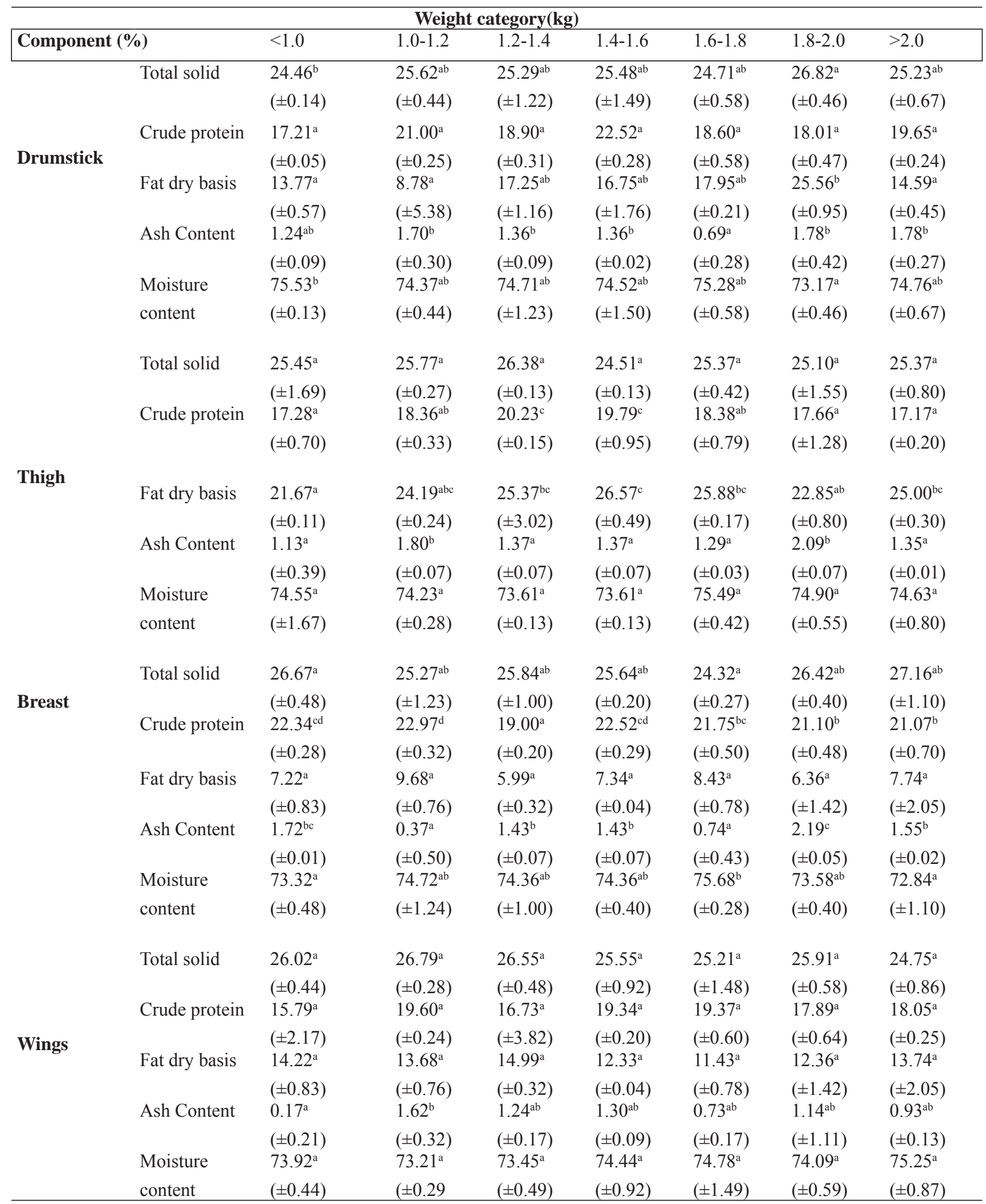

abcd different letters in the same row are significantly different at $\mathrm{p}<0.05$, Parenthesis indicates standard deviation.

The highest crude protein value was observed in breast part and lowest in thigh and wing portion. Total solid content don't vary with different weight categories. The highest fat contents is observed in thigh; lowest is from breast. Cooking yield was significantly affected by dress carcass weight and highest cooking yield $(85.93 \% \pm 0.93)$ was observed in more 
than $2 \mathrm{~kg}$ of weight category that was almost due to a meat yield. There was a significant difference $(\mathrm{p}<0.05)$ observed for cooking yield at $0 \mathrm{hr}$ and $48 \mathrm{hr}$ after slaughtering. $\mathrm{pH}$ values was significantly affected by time duration after slaughtering but there was slight decline (Table 5). This result is in agreement with Ali et al., (1999). That low rate in $\mathrm{pH}$ decline indicates that the animals were not under stress when slaughtered. Moisture contents were not significantly affected by dress carcass weight or time duration at $\mathrm{p}>0.05$ (Table 4, Table 5).

Table 4. Variation of cooking yield, moisture content and $\mathrm{pH}$ of breast meat in different weight category

\begin{tabular}{|c|c|c|c|}
\hline Weight category (Kg) & $\begin{array}{l}\text { Cooking yield } \\
(\%) \\
\end{array}$ & $\begin{array}{c}\text { Moisture content } \\
(\%) \\
\end{array}$ & pH \\
\hline \multirow[t]{2}{*}{$<1.0$} & $71.28^{\mathrm{c}}$ & $74.86^{\mathrm{b}}$ & $5.62^{d}$ \\
\hline & \pm 1.78 & \pm 0.39 & \pm 0.03 \\
\hline \multirow[t]{2}{*}{$1.0-1.2$} & $79.88^{b}$ & $75.26^{\mathrm{a}}$ & $5.72^{b}$ \\
\hline & \pm 6.96 & \pm 0.36 & \pm 0.03 \\
\hline \multirow[t]{2}{*}{$1.2-1.4$} & $82.21^{\mathrm{a}}$ & $74.47^{\mathrm{c}}$ & $5.62^{d}$ \\
\hline & \pm 1.88 & \pm 0.35 & \pm 0.04 \\
\hline \multirow[t]{2}{*}{$1.4-1.6$} & $85.07^{\mathrm{a}}$ & $74.83^{\mathrm{bc}}$ & $5.73^{c}$ \\
\hline & \pm 1.85 & \pm 0.23 & \pm 0.01 \\
\hline \multirow[t]{2}{*}{$1.6-1.8$} & $83.63^{a b}$ & $75.16^{\mathrm{ab}}$ & $5.72^{\mathrm{c}}$ \\
\hline & \pm 1.41 & \pm 0.31 & \pm 0.02 \\
\hline \multirow[t]{2}{*}{$1.8-2.0$} & $84.90^{\mathrm{a}}$ & $74.81^{b c}$ & $5.78^{\mathrm{a}}$ \\
\hline & \pm 1.49 & \pm 0.52 & \pm 0.00 \\
\hline \multirow[t]{2}{*}{$>2.0$} & $85.93^{\mathrm{a}}$ & $75.19^{\mathrm{ab}}$ & $5.80^{\mathrm{a}}$ \\
\hline & \pm 0.93 & \pm 0.54 & \pm 0.00 \\
\hline
\end{tabular}

abcd different letters in the same column are significantly different at $\mathrm{p}<0.05$, (Mean $\pm \mathrm{SD}$ )

Table 5. Variation of cooking yields, moisture content and $\mathrm{pH}$ of breast meat at different time

\begin{tabular}{|c|c|c|c|}
\hline Time after slaughtering & $\begin{array}{c}\text { Cooking yield } \\
(\%) \\
\end{array}$ & $\begin{array}{c}\text { Moisture content } \\
(\%) \\
\end{array}$ & Mean pH \\
\hline \multirow[t]{2}{*}{$0 \mathrm{hr}$} & $83.55^{\mathrm{a}}$ & $74.94^{b}$ & $5.79^{a}$ \\
\hline & \pm 0.96 & \pm 0.43 & \pm 0.00 \\
\hline \multirow[t]{2}{*}{$12 \mathrm{hr}$} & $82.64^{\mathrm{ab}}$ & $74.63^{c}$ & $5.67^{\mathrm{c}}$ \\
\hline & \pm 1.90 & \pm 0.27 & \pm 0.00 \\
\hline \multirow[t]{2}{*}{$24 \mathrm{hr}$} & $83.30^{\mathrm{a}}$ & $75.45^{a}$ & $5.70^{\mathrm{d}}$ \\
\hline & \pm 1.56 & \pm 0.21 & \pm 0.03 \\
\hline \multirow[t]{2}{*}{$36 \mathrm{hr}$} & $81.41^{\mathrm{ab}}$ & $74.63^{c}$ & $5.76^{\mathrm{b}}$ \\
\hline & \pm 1.65 & \pm 0.58 & \pm 0.04 \\
\hline \multirow[t]{2}{*}{$48 \mathrm{hr}$} & $79.74^{b}$ & $75.04^{b}$ & $5.69^{\mathrm{d}}$ \\
\hline & \pm 5.57 & \pm 0.44 & \pm 0.04 \\
\hline
\end{tabular}

abcd different letters in the same column are significantly different at $\mathrm{p}<0.05$, (Mean $\pm \mathrm{SD}$ ) 
Table 6. Regression equations for the relationship between dress weight (DW) and live weight (LW) of broiler chicken

\begin{tabular}{|c|c|c|c|}
\hline DW & Equation & $\mathrm{R}^{2}$ & Significance $^{1}$ \\
\hline \multicolumn{4}{|l|}{ Distance } \\
\hline$<50 \mathrm{~km}$ & $=-111.26+0.84 \mathrm{LW}$ & 0.983 & $* *$ \\
\hline $50-100 \mathrm{~km}$ & $=62.96+0.75 \mathrm{LW}$ & 0.968 & $* *$ \\
\hline $100-150 \mathrm{~km}$ & $=-22.02+0.80 \mathrm{LW}$ & 0.967 & $* *$ \\
\hline$>150 \mathrm{~km}$ & $=-2177.94+2.78 \mathrm{LW}-2.41 \mathrm{LW}^{3}$ & 0.643 & $* *$ \\
\hline \multicolumn{4}{|l|}{ Starvation time } \\
\hline$<14 \mathrm{hrs}$ & $=-40.26+0.81 \mathrm{LW}$ & 0.996 & $* *$ \\
\hline $16-18 \mathrm{hrs}$ & $=-54.23+0.81 \mathrm{LW}$ & 0.968 & $* *$ \\
\hline $24-26 \mathrm{hrs}$ & $=79.14+0.73 \mathrm{LW}$ & 0.844 & $* *$ \\
\hline \multicolumn{4}{|l|}{ Life Span } \\
\hline$<35$ days & $=-40.256+0.81 \mathrm{LW}$ & 0.996 & $* *$ \\
\hline $35-40$ days & $=-59.60+0.81 \mathrm{LW}$ & 0.943 & $* *$ \\
\hline 40-45 days & $=39.37+0.76 \mathrm{LW}$ & 0.962 & $* *$ \\
\hline \multicolumn{4}{|l|}{ Rearing System } \\
\hline Open & $=-30.89+0.796 \mathrm{LW}$ & 0.948 & $* *$ \\
\hline Close & $=-40.26+0.81 \mathrm{LW}$ & 0.996 & $* *$ \\
\hline \multicolumn{4}{|c|}{ Weight Categories } \\
\hline $1200-1400 \mathrm{~g}$ & $=-40.26+0.81 \mathrm{LW}$ & 0.996 & $* *$ \\
\hline $1400-1600 \mathrm{~g}$ & $=-59.61+.81 \mathrm{LW}$ & 0.944 & $* *$ \\
\hline $1600-1800 \mathrm{~g}$ & $=39.37+0.76 \mathrm{LW}$ & 0.962 & $* *$ \\
\hline $1800-2000 \mathrm{~g}$ & $=16.66+0.84 \mathrm{LW}$ & 0.957 & $* *$ \\
\hline$>2000 \mathrm{~g}$ & $=-101.4+0.83 \mathrm{LW}$ & 0.948 & $* *$ \\
\hline
\end{tabular}

$1 * *$ Regression models are significant at $\mathrm{p} \leq 0.01$

Regression analyses were conducted on the relationship between dress weight and live weight. The reported relationship between broiler live weight and dress weight with giblets and without giblets were $-34.63+0.8 \mathrm{LW}\left(\mathrm{R}^{2}=\right.$ $0.957)$ and $-83.81+0.78 \mathrm{LW}\left(\mathrm{R}^{2}=0.954\right)$ respectively. Both were significant at $\mathrm{p}<0.01$ level. Starvation period, life span, transport distance, rearing system and live dress weight categories affect to the final dress weight of the broilers. Regression equations are presented in Table 6 to assist the calculation of dress weight based on live weight for different variables. The broiler dress weight from different categories can be determined by follow those different equations.

\section{Conclusions}

The trait of economic importance is the dressing percentage and this tends to increase as the slaughter weight increased up to $2.0 \mathrm{~kg}$ live weight. Based on the dressing percentage, weight of total edible meat, it may be concluded that broiler chickens are optimally slaughtered up to $2.0 \mathrm{~kg}$ live weight. Live and dress weight had significant relationship with the transport distance, starvation period, life time, cage system and live weight category.

\section{References}

Acar N., Moran E. T. and Mulvaney D. R. (1993). Breast muscle development of commercial broilers from hatching to twelve weeks of age. Poult. Sci. 73: 317-25.

Ali A. S. A., Harrison H. P. and Jensen J. F. (1999). Effect of some ante- mortem stressors on peri-mortem and postmortem biochemical changes and tenderness in broiler breast muscle: a review. Poult. Sci. 55:403-414

AOAC (1980). Official Methods of Analysis. 13 ${ }^{\text {th }}$ ed. Association of Official Analytical Chemists. Washington D.C.

Bouwkamp E. L., Bigbee D. E. and Wabeck C. J. (1973). Strain influences on broiler parts yield. Poult. Sci. 52:15171523. 
Department of animal production and health report, (2012). Livestock data, Department of animal production and health, Colombo, Sri Lanka

Guenter W., Campbell L. D and Johnson D. E. (1995). Comparative feeding programmes for growing poultry. Pages 325-330 in Poultry production. In: Hunton, P. ed. Elsevier, London.

Heath J. L. (1979). Factors affecting quality, yields and consumer acceptance of broiler halves. Poult. Sci. 58:350354.

Honikel K. O. (1998). Reference methods for the assessment of physical characteristics of meat. Meat Sci. 49: 447-457.

Lewis P. D., Perry G. C., Farmer L. J. and Patterson R. L. S. (1997). Responses of two genotypes of chicken to the diets and stocking densities typical of UK and Label Rouge production systems: I. Performance, behaviour and carcass composition. Meat Sci. 45: 501-516.

Mcnally E. H. and Spicknall N. H. (1949). Meat yield from live, dressed, and eviscerated Rhode Island Red males of broiler, fryer, and light roaster weights. Poult. Sci. 28:562567

Moran E. T. Jr., and Orr H. L. (1969). A characteristic of chicken broilers as a function of sex and age; live performance, processing, grade and cooking yield. Food Tech. 23: 91-98

Moran E. T. and Larmond E. (1970). Dressing, grading and meat yields with broiler chicken breed. Food Tech. 24: 73-80.

Oluyemi J. A. and Roberts F. A. (2000). Poultry production in warm wet climates. Macmillan Press Ltd. London.

Orr H.L. and Hunt, E.C. (1984) Yield of carcass, parts, meat, skin and bone of eight strains of broilers. Poult. Sci. 63:2197-2200.

Petracci M., Betti M., Bianchi M. and Cavani C. (2004). Color Variation and Characterization of broiler breast meat during processing in Italy. Poult. Sci. 83: 2086-2092.

Rickefes (1985). Modification of growth and development of mescles in poultry. Poult.Sci. 64: 1563-1576.

Suto Z., Horn P., Jensen J. F., Sorensen P. and Csapo J. (1998). Carcass traits, abdominal fat deposition and chemical composition of commercial meat type chicken during a twenty growing period. Arch. Geflügelk. 62: $21-25$.
Yavuz C., Sava S. and Hakan G. (2004). The effect of the sale of whole or cut up chicken meat on enterprise income according to season. Turk J Vet Anim Sci, 28: 399-402

Young L. L., Northcutt J. K., Buhr R. J., Lyon C. E. and Wane G. O. (2001). Effects of age, sex and duration of postmortem aging on percentages yield of parts from broiler chicken carcasses. Poult. Sci. 80: 376-379. 